\title{
Parental Influence on Early Childhood Caries
}

\author{
Sanam Faheem ${ }^{1}$ \\ Shahida Maqsood ${ }^{2}$ \\ Faheem Shaikh ${ }^{3}$ \\ BDS \\ BDS, M.Phil \\ BDS
}

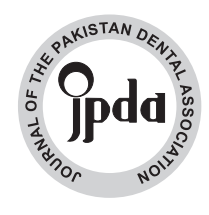

OBJECTIVE: Parents have a significant role in educating their children about oral hygiene, therefore their knowledge and attitude influences their children oral health status.

METHODOLOGY: In this cross-sectional study questionnaires were distributed to 300 mothers from Dow Dental College OPD to assess their knowledge, attitude and practice towards their children oral health. Questionnaire assessed demographic data, literacy level, importance of primary dentition and aspects of early childhood decay. Data was analyzed by SPSS version 20. P Values was considered significant at $p<0.05$. Associations between multiple variables were assessed by using chi square and multinomial logistic regression analysis.

RESULTS: Majority $(\mathrm{n}=167,55.7 \%)$ had fair knowledge, $23.3 \%(\mathrm{n}=70)$ reported to exhibit fair attitude while $47 \%$ $(n=141)$ reported acceptable oral hygiene practices. While majority mothers $(96.7 \%, n=290)$ knew that sugar is the main cause of caries but in practice many of them were giving their children sweet upon demand (60.7\%, n=182). Only 127 participants $(42.3 \%)$ knew about the role of fluoride. Positive attitude towards primary dentition was shown by 169 participants $(56.3 \%)$.

CONCLUSIONS: Overall very few mothers had good knowledge towards their children's oral health which resulted in the poor practices of oral hygiene.

KEY WORDS: Caries, Oral Health Knowledge, Oral Hygiene Practice, Parental Awareness.

HOW TO CITE: Faheem S, Maqsood S, Shaikh F. Parental influence on early childhood caries. J Pak Dent Assoc 2018;27(4):195-01.

DOI: https://doi.org/10.25301/JPDA.274.195

Received: 31 January 2018, Accepted: 19 June 2018

\section{INTRODUCTION}

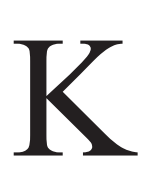
nowledge and attitudes of parents may play an important role in moulding behaviour of their children toward health and hygiene. ${ }^{1}$ Similarly, parental Oral health knowledge and belief may positively impact child's oral health. ${ }^{2}$ According to American Academy of Pediatric Dentistry "Early Childhood Caries (ECC) is defined as the presence of one or more primary teeth with caries in a child 6 years or younger". ${ }^{3}$ ECC is highly prevalent disease worldwide; its prevalence among Pakistani children is $44.4 \%$. ${ }^{3}$ Worldwide disease burden of the ECC varies greatly. In Europe, the disease is not very common, prevalence ranges in Sweden from 11.4\% among 3 to 6 year old children to $19.0 \%$ in Italy. ${ }^{4}$ High Prevalence is seen in middle east countries, like Palestine (76\%), and UAE $(83 \%)$. A prevalence of $51.9 \%$ was reported from India. ${ }^{5}$

1. Postgraduate Trainee of Msc, Department of Oral Biology (Dental), Dow University of Health Sciences.

2. Assistant Professor, Department of Oral Biology, Dow Dental College, Dow University of Health Sciences.

3. Dental Practitioner, Department of Oral Biology, London Dental Hospital Karachi. Corresponding author: "Dr. Sanam Faheem" < sanamfaheem4479@gmail.com >
It has been documented in previous researches that children who develop ECC are at high risk of developing caries in permanent dentition which results in long episodes of treatments and visits to dentists and hence affects the quality of life. ${ }^{5}$ There are many factors contributing to its development like excessive consumption of sugar containing food, less frequent tooth brushing habits with prolong breast feeding or falling asleep while feeding sweet or flavoured milk. ${ }^{6}$ Parents and caregivers play very important role in infant's oral health as evidences shows that mother's awareness of oral hygiene and its practices from pregnancy is good source of establishing infant's good oral health. ${ }^{7}$

Age and educational level are broadly associated with parental knowledge and their practice towards oral hygiene, as its been observed that children of young parents with low socioecnomical status and less knowledge are more prone to decay and premature loss of deciduous teeth. ${ }^{8}$ Establishing good oral hygiene in early few years of child's life includes regular brushing at early age assisted by mothers, their regular visits to dentists for prevention of premature loss of primary teeth is very important. In a developing country like Pakistan, majority parents are not taking their children oral 
problems as serious health issue due to their lack of proper oral health knowledge.It has been observed that there is an increased incidence of early childhood caress due to lack of knowledge of ECC among parents. Therefore, the primary goal of the study was to assess the parental influence on ECC by assessing the relationship between age and education with knowledge, attitude and practices of parents visiting Dow Dental College OPD.

\section{METHODOLGY}

In this cross-sectional study questionnaires were distributed to 300 mothers from Dow Dental College OPD to assess their knowledge, attitude and practice towards their children oral health. Sample size was calculated after reviewing the sample size in an article by Shetty et. al. and determining the population size (that is the number of patients with children visiting Dow Dental OPD). ${ }^{1}$ By using software open Epi ${ }^{R}$ keeping standard error of mean 5\% with confidence interval of 95\%, calculated sample was 298 . Consent was taken before starting from all participants regarding to fill the questionnaire. All married couples having at least one normal child were included in the study. Children guardian or caretakers or special needs children were not included. Purposive sampling was used to recruit study participants. Self administered questionnaire was used in this study. The demographic data relating to area of residence, educational level and occupation were asked from the participants. Aspects of ECC and the knowledge of importance of primary teeth in child's growth and development, oral hygiene practices, nursing habits and role of diet and fluoride in maintaining oral hygiene were assessed.

\section{Data Analysis}

Data was analyzed by SPSS version 20. P Values was considered significant when $<0.05$ (confidence interval of 95\%). Descriptive statistics of demographic variables, knowledge, attitude and practice were presented as mean, standard deviation, frequency and percentages. For Inferential statistics responses were scored and were categorized into good, fair and poor. Further analysis to see the associations between multiple variables were done by using chi square and multinomial logistic regression analysis.

\section{RESULTS}

A total of 300 questionnaires were filled. Responses were assessed by scoring them based on Good, fair and poor. The demographic data is presented in Table: 1 , which shows majority were Mothers (99\%), falling in age from $<30$ years (55.7\%), most had primary educational level and were housewives (84.3\%). Maximum patients were from Karachi South area.

Table: 2 represents the response of parents, a total of 122 participants $(40.7 \%)$ of parents knew about the right time of first deciduous tooth eruption, most of them had no idea about the total number of deciduous teeth (66\%). Two thirds knew that milk teeth are equally prone to decay $(67 \%)$. Almost all of parents $(96 \%, \mathrm{n}=290)$ knew that sugar commonly

Table 1: Demographic Variables

\begin{tabular}{|c|l|c|c|}
\hline \multirow{2}{*}{ Sex } & & $n$ & $\%$ \\
\hline \multirow{3}{*}{ Age (in years) } & Females & 296 & 98.7 \\
\cline { 2 - 4 } & Males & 4 & 1.3 \\
\cline { 2 - 4 } & $<30$ & 167 & 55.7 \\
\cline { 2 - 5 } & $30-45$ & 119 & 39.7 \\
\cline { 2 - 5 } & $>45$ & 14 & 4.7 \\
\hline \multirow{2}{*}{ Occupation } & Working & 47 & 15.7 \\
\cline { 2 - 5 } & House Ridden & 253 & 84.3 \\
\hline \multirow{2}{*}{ Education Level } & $\begin{array}{l}\text { Educated (from secondary to } \\
\text { post graduate) }\end{array}$ & 176 & 58.7 \\
\cline { 2 - 5 } & $\begin{array}{l}\text { Un-educated (primary \& no } \\
\text { education) }\end{array}$ & 122 & 41.3 \\
\hline
\end{tabular}

Table 2: Response of Parents

\begin{tabular}{|c|c|c|}
\hline & $\mathrm{n}$ & $\%$ \\
\hline \multicolumn{3}{|l|}{ KNOWLEDGE } \\
\hline Time of first deciduous tooth eruption & 122 & 40.7 \\
\hline Time of first permanent tooth eruption & 82 & 27.3 \\
\hline Importance of Fluoride & 127 & 42.3 \\
\hline Role of Sugar in causing caries & 290 & 96.7 \\
\hline Ideal time of brushing & 40 & 13.3 \\
\hline Common Dental Problem among Children is Decay & 152 & 50.7 \\
\hline \multicolumn{3}{|l|}{ ATTITUDE } \\
\hline Regular Dental Check-ups & 211 & 70 \\
\hline Role of Mother in Assisting OH Practice & 273 & 91 \\
\hline Maintenance of Deciduous Dentition & 103 & 34.3 \\
\hline Importance of primary teeth & 169 & 56.3 \\
\hline \multicolumn{3}{|l|}{ PRACTICE } \\
\hline Importance of Brushing Twice Daily & 139 & 46.3 \\
\hline Importance of rinsing after every meal & 151 & 50.3 \\
\hline Sweet consumption upon child's demand & 182 & 60.7 \\
\hline Tools used to clean teeth other than Tooth Paste \& Brush & 31 & 10.3 \\
\hline Replacement of Tooth Brush@3 months & 137 & 45.7 \\
\hline
\end{tabular}


Association between

Knowledge, Attitude and practice with age groups and educational level by logistic regression analysis.

Keeping Education level constant, logistic regression suggests for is 0.913 times chance of having good knowledge and 1.006 times chance of having fair knowledge than poor.

Keeping age constant:

a) There is 4.52 times chance for graduates to have good knowledge than fair knowledge.

b) There is 0.50 times chance for intermediates to have good knowledge than fair knowledge. c) There is 0.20 times chance for respondents having at least primary education to have good knowledge than fair knowledge. respondents having at least primary education to have good knowledge than fair knowledge. every "year" increase in age there d) There is 0.30 times chance for

Table 3-a

KNOWLEDGE

\begin{tabular}{|c|c|c|c|c|c|c|c|c|c|}
\hline \multirow{2}{*}{\multicolumn{2}{|c|}{ categories of knolwedge ${ }^{a}$}} & \multirow{3}{*}{$\frac{B}{3.717}$} & \multirow{3}{*}{$\begin{array}{c}\begin{array}{c}\text { Std. Er- } \\
\text { ror }\end{array} \\
1.270\end{array}$} & \multirow{3}{*}{$\frac{\text { Wald }}{8.569}$} & \multirow[b]{2}{*}{ df } & \multirow[b]{2}{*}{ Sig. } & \multirow[b]{2}{*}{$\operatorname{Exp}(B)$} & \multicolumn{2}{|c|}{$\begin{array}{c}95 \% \text { Confidence Interval for } \\
\operatorname{Exp}(B)\end{array}$} \\
\hline & & & & & & & & Lower Bound & Upper Bound \\
\hline \multirow[t]{8}{*}{ Good } & Intercept & & & & 1 & .003 & & & \\
\hline & Age & -.091 & .038 & 5.924 & 1 & .015 & .913 & 848 & .982 \\
\hline & [Post Graduates] & -22.128 & .000 & & 1 & & $2.454 E-10$ & $2.454 E-10$ & $2,454 E-10$ \\
\hline & [Graduates] & -3.952 & .920 & 18.473 & 1 & .000 & .019 & .003 & 117 \\
\hline & [Intermediates] & -2.181 & .756 & 8.314 & 1 & .004 & .113 & .026 & 497 \\
\hline & $\begin{array}{l}\text { [Secondary educa- } \\
\text { tion] }\end{array}$ & -2.567 & .774 & 11.013 & 1 & .001 & .077 & .017 & .350 \\
\hline & $\begin{array}{l}\text { [Primary educa- } \\
\text { tion] }\end{array}$ & -1.782 & .720 & 6.133 & 1 & .013 & .168 & .041 & 690 \\
\hline & [No Education] & $\theta^{b}$ & . & & 0 & & & & \\
\hline \multirow[t]{8}{*}{ Fair } & Intercept & 1.860 & .835 & 4.956 & 1 & .026 & & & \\
\hline & Age & .006 & .020 & .080 & 1 & .778 & 1.006 & .966 & 1.047 \\
\hline & [Post Graduates] & -21.631 & 5173.103 & .000 & 1 & .997 & 4.035E-10 & .000 & $\therefore$ \\
\hline & [Graduates] & -3.175 & .580 & 29.974 & 1 & .000 & .042 & .013 & .130 \\
\hline & [Intermediates] & -1.484 & .579 & 6.566 & 1 & .010 & .227 & .073 & .705 \\
\hline & $\begin{array}{l}\text { [Secondary educa- } \\
\text { tion] }\end{array}$ & -1.278 & .548 & 5.444 & 1 & .020 & 278 & .095 & .815 \\
\hline & $\begin{array}{l}\text { [Primary Educa- } \\
\text { tion] }\end{array}$ & -.822 & .569 & 2.090 & 1 & .148 & .439 & 144 & 1.340 \\
\hline & [No Education] & $\sigma^{\infty}$ & . & . & 0 & & & . & \\
\hline
\end{tabular}

a. The reference category is: poor.

Table 3-b

ATTITUDE

\begin{tabular}{|c|c|c|c|c|c|c|c|c|c|}
\hline \multirow{2}{*}{\multicolumn{2}{|c|}{ categories of attitude ${ }^{a}$}} & \multirow{3}{*}{$\begin{array}{c}B \\
-3.595\end{array}$} & \multirow{3}{*}{$\begin{array}{l}\begin{array}{l}\text { Std. Er- } \\
\text { ror }\end{array} \\
1.663\end{array}$} & \multirow{3}{*}{$\begin{array}{l}\text { Wald } \\
4.673\end{array}$} & \multirow{3}{*}{$\frac{d f}{1}$} & \multirow{3}{*}{$\begin{array}{l}\text { Sig. } \\
.031\end{array}$} & \multirow{3}{*}{$\operatorname{Exp}(B)$} & \multicolumn{2}{|c|}{$\begin{array}{l}95 \% \text { Confidence Interval for } \\
\operatorname{Exp}(B)\end{array}$} \\
\hline & & & & & & & & \multirow[t]{2}{*}{ Lower Bound } & \multirow[t]{2}{*}{ Upper Bound } \\
\hline \multirow[t]{8}{*}{ Good } & Intercept & & & & & & & & \\
\hline & Age & .048 & .045 & 1.097 & 1 & .295 & 1.049 & .959 & 1.146 \\
\hline & [Post Graduates] & -19.277 & .000 & - & 1 & . & $\begin{array}{r}4.248 E- \\
9\end{array}$ & 4.248E-9 & 4.248E-9 \\
\hline & [Graduates] & -19.286 & 6223.273 & .000 & 1 & .998 & $\begin{array}{r}4.210 E- \\
g\end{array}$ & .000 & $b$ \\
\hline & [Intermediates] & -18.912 & 7301.164 & .000 & 1 & .998 & $\begin{array}{r}6.119 E- \\
9\end{array}$ & .000 & b \\
\hline & $\begin{array}{l}\text { [Secondary educa- } \\
\text { tion] }\end{array}$ & -.864 & .742 & 1.357 & 1 & .244 & .421 & .098 & 1.804 \\
\hline & $\begin{array}{l}\text { [Primary educa- } \\
\text { tion] }\end{array}$ & -18.998 & 5602.793 & .000 & 1 & .997 & $\begin{array}{r}5.613 E- \\
9\end{array}$ & .000 & b \\
\hline & [No Education] & $\sigma^{\sigma}$ & . & . & 0 & . & . & . & . \\
\hline \multirow[t]{8}{*}{ Fair } & Intercept & -1.012 & .791 & 1.640 & 1 & .200 & & & \\
\hline & Age & -.025 & .022 & 1.360 & 1 & .244 & .975 & .935 & 1.017 \\
\hline & [Post Graduates] & .202 & .876 & .053 & 1 & .818 & 1.224 & .220 & 6.814 \\
\hline & [Graduates] & .272 & .550 & .245 & 1 & .620 & 1.313 & .447 & 3.861 \\
\hline & [Intermediates] & 1.594 & .506 & 9.926 & 1 & .002 & 4.921 & 1.826 & 13.263 \\
\hline & $\begin{array}{l}\text { Secondary educa- } \\
\text { tion] }\end{array}$ & .116 & .535 & .047 & 1 & .829 & 1.123 & .394 & 3.201 \\
\hline & $\begin{array}{l}\text { [Primary educa- } \\
\text { tion] }\end{array}$ & .957 & .487 & 3.854 & 1 & .050 & 2.603 & 1.002 & 6.764 \\
\hline & [No Education] & $\sigma$ & . & . & 0 & . & . & . & . \\
\hline
\end{tabular}

a. The reference category is: poor.

causes decay in early age. Most of the mothers believed that brushing should be started at 3-4 years of age $(65 \%)$ however only $14.7 \%$ mothers accepted that ideal time of brushing is after the eruption of first primary tooth. Almost half $(46 \%)$ believed that regular brushing could prevent early childhood decay. Awareness regarding role of fluoridated tooth paste was in less than the half of participants (42.3\%). Parents of most chileren(70\%) agreed that the child should have regular checkup but were not in practice of doing so. 
Table 3-c

PRACTICE

Keeping education constant, for every "Year" increase in age, there is 0.992 times chance for respondents to acquire good habit of practice, and 0.943 times chance to acquire fair habit of practice than poor.

Keeping age constant:

a) There is 0.37 times chance for graduates to adapt good knowledge over fair b) There is 0.58 times chance for intermediates to adapt good knowledge over fair

c) There is 0.54 times chance for respondents having secondary education to adapt good knowledge over fair.

d) There is 0.80 times chance for respondents having at least primary education to adapt good knowledge over fair.

\begin{tabular}{|c|c|c|c|c|c|c|c|c|c|}
\hline \multirow{2}{*}{\multicolumn{2}{|c|}{ categories of practice ${ }^{a}$}} & \multirow{3}{*}{$\frac{B}{2.178}$} & \multirow{3}{*}{$\begin{array}{c}\begin{array}{c}\text { Std. Er- } \\
\text { ror }\end{array} \\
.971\end{array}$} & \multirow{3}{*}{$\frac{\text { Wald }}{5.033}$} & \multirow[b]{2}{*}{$d f$} & \multirow[b]{2}{*}{ Sig. } & \multirow[b]{2}{*}{$\operatorname{Exp}(B)$} & \multicolumn{2}{|c|}{$\begin{array}{l}95 \% \text { Confidence Interval for } \\
\text { Exp(B) }\end{array}$} \\
\hline & & & & & & & & \multirow[t]{2}{*}{ Lower Bound } & \multirow[t]{2}{*}{ Upper Bound } \\
\hline Good & Intercept & & & & 1 & .025 & & & \\
\hline & Age & .008 & .024 & .111 & 1 & .739 & .992 & .946 & 1.040 \\
\hline & [Post Graduates] & -22.778 & .000 & & 1 & . & $1.281 E-10$ & $1.281 E-10$ & $1.281 E-10$ \\
\hline & [Graduates] & -2.711 & .670 & 16.387 & 1 & .000 & .066 & .018 & .247 \\
\hline & [Intermediates] & -.546 & .778 & .494 & 1 & .482 & .579 & .126 & 2.658 \\
\hline & $\begin{array}{l}\text { [Secondary educa- } \\
\text { tion] }\end{array}$ & -1.919 & 632 & 9.223 & 1 & .002 & .147 & .043 & .506 \\
\hline & $\begin{array}{l}\text { [Primary educa- } \\
\text { tion] }\end{array}$ & .548 & .687 & .636 & 1 & .425 & .578 & .151 & 2.221 \\
\hline & [No Education] & $\infty^{\infty}$ & - & & 0 & & . & & . \\
\hline \multirow[t]{8}{*}{ Fair } & Intercept & 2.340 & .910 & 6.613 & 1 & .010 & & & \\
\hline & Age & -.015 & .022 & .488 & 1 & .485 & 985 & .943 & 1.028 \\
\hline & [Post Graduates] & -2.544 & 817 & 9.703 & 1 & .002 & .079 & .016 & 389 \\
\hline & [Graduates] & -1.744 & 622 & 7.875 & 1 & .005 & .175 & .052 & .591 \\
\hline & [Intermediates] & -.004 & .764 & .000 & 1 & .996 & .996 & .223 & 4.450 \\
\hline & $\begin{array}{l}\text { [Secondary educa- } \\
\text { tion] }\end{array}$ & -1.306 & .616 & 4.497 & 1 & .034 & .271 & .081 & .906 \\
\hline & $\begin{array}{l}\text { [Primary educa- } \\
\text { tion] }\end{array}$ & -327 & .684 & .228 & 1 & .633 & .721 & .189 & 2.757 \\
\hline & [No Education] & $\sigma^{\infty}$ & & & 0 & & & & \\
\hline
\end{tabular}

a. The reference category is: poor.

Association between Knowledge, Attitude and practice with Educational level and Age by using Multinomial logistic regression \& chi square tests.

Table: 3-a, 3-b and 3-c shows Logistic regression which demonstrated 4.52 odds for graduates to have good knowledge, when age was kept constant. When education was kept constant, odds ratio was 4.921 for intermediates to have fair attitude.

Table: 4 shows results of Chi square which demonstrated significant association of knowledge $(0.042,0.001)$ and practice $(0.005,0.000)$ with age and educational level however attitude was not found to a significant association

\section{Pearson Chi square analysis}

Table: 4 Pearson Chi square (Asymp.sig 2-sided)

\begin{tabular}{|c|c|c|}
\hline & Age Group & Educational Level \\
\hline Knowledge & 0.644 & $0.000^{*}$ \\
\hline Attitude & 0.345 & $0.000^{*}$ \\
\hline Practice & 0.328 & $0.000^{*}$ \\
\hline
\end{tabular}

with both of them.

While Figure 4-a, 4-b, 4-c, 4-d, 4-e, 4-f shows bar charts relating to above results.

\section{Bar Charts showing Association of Education with Knowledge, attitude and Practice by using Pearson chi-square test}

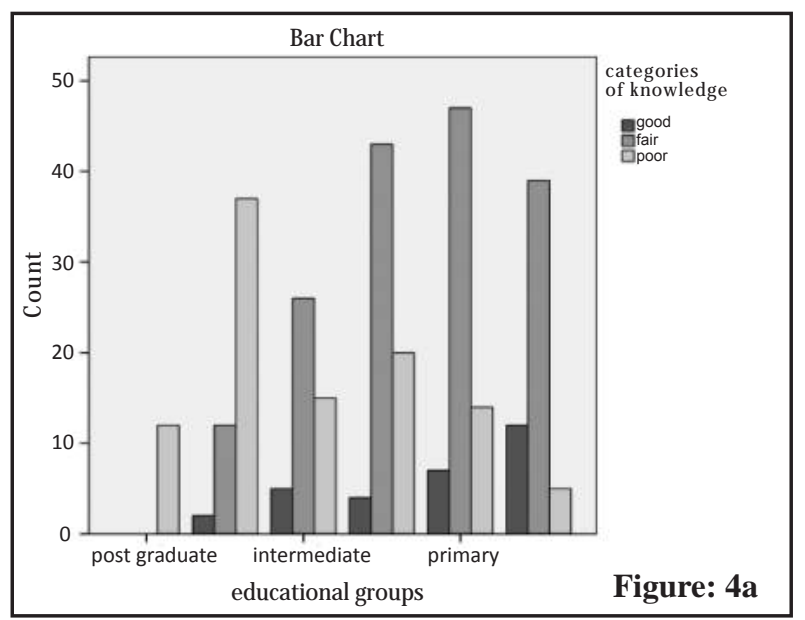

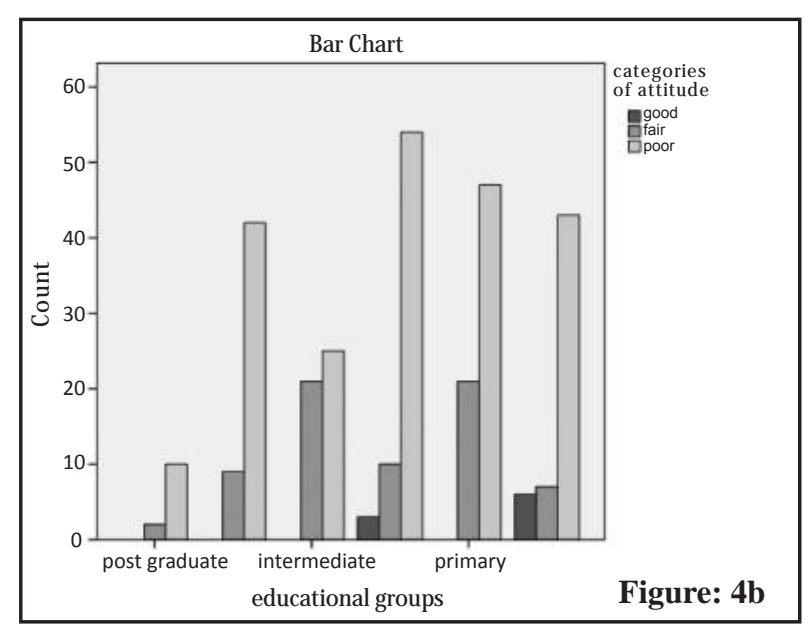





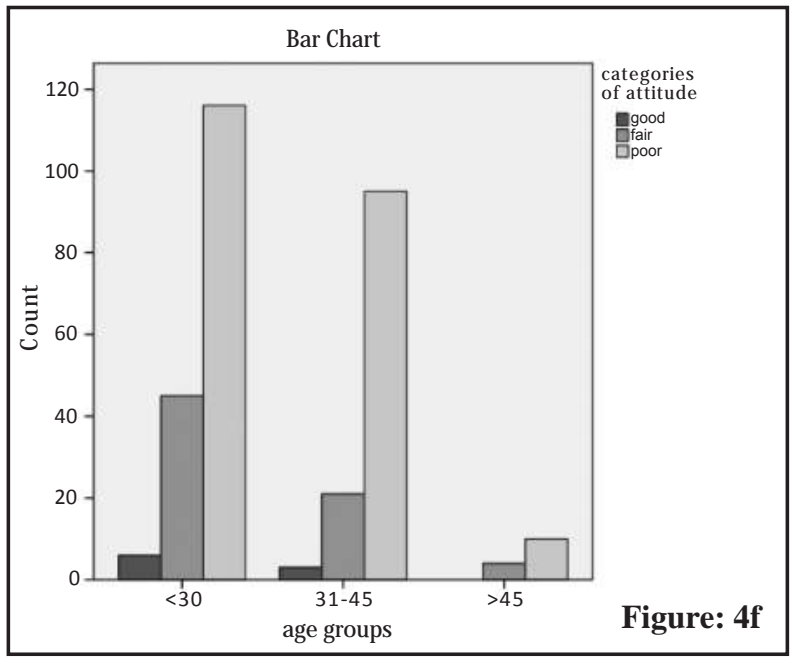

DISCUSSIONS

Mothers are considered as role models for their children. ${ }^{1}$ Childs oral health is strongly associated with mother's oral hygiene practices and are established during infancy and practiced throughout life..$^{9}$ As Pakistan is still a developing country very few studies have been conducted in Pakistan regarding Parental influence on ECC. This study provides a new data about the awareness of mothers towards the oral hygiene of their children as the questionnaire focuses on basic knowledge and importance of primary teeth as they are important for child's growth and development. In this study $40.7 \%$ of the mothers knew the right time for first deciduous tooth eruption however $66 \%$ had no idea about the numbers of total deciduous teeth, most of the mothers thought that only anterior four teeth are deciduous teeth, findings were in agreement to a study conducted in India. ${ }^{10}$ Majority of the mothers knew about the dietary and feeding practices, $96.7 \%$ knew that excessive consumption of sugar cause early decay and these findings were consistent with other previous studies conducted in Pakistan, India and Malaysia. . $^{1,811}$

In our society, most people think the primary teeth are temporary and its treatment is waste of time and money. ${ }^{12}$ In our study, only $56.3 \%$ of mothers were aware of importance of primary teeth.

Pertaining to prevention of dental caries, $46 \%$ of mothers believe that regular brushing twice a day with fluoride toothpaste can help in reducing dental pain, findings were very close to a study in Mumbai ${ }^{10}$ More than half of participants had no idea that tooth paste should have fluoride or not (finding were consistent with study in india ${ }^{10}$ ) $42.3 \%$ knew that they use fluoride toothpaste at home. When questioned about importance of fluoride only 30\% agreed that it can prevent or arrest early decays which is slightly 
lower than in the other study. ${ }^{8}$ This finding is contrary to a study conducted in Malaysia showed that reported excellent (85\%) knowledge of mothers. ${ }^{11}$ However similar lower results were also seen in India. ${ }^{10}$ Mothers of $91 \%$ children believed that childrens' early brushing should be supervised by them. The ratio is close to results of India but contrary to the results of study from Pakistan which stated that $96 \%$ of mothers did not know that they should supervise their children for brushing. ${ }^{8} 10$ Majority of the parents believe that cleaning of teeth should commence at age when all milk teeth have erupted (at 3-4 years) which is much higher than the ideal age for the start of brushing. Our results are consistent with the findings of Riyadh and India. ${ }^{13,10}$

The status of first molar has been studied in many studies to assess the oral health status of children because its early loss results in multiple problems in occlusion and function. ${ }^{14}$ Our results were slightly less than the findings found in Jordan. ${ }^{14}$

More than $80 \%$ of children use tooth paste and toothbrush for cleaning. These findings were in line with the other study in India. ${ }^{10}$

Almost half of mothers (46\%) reported that their children are brushing twice a day, which is quite close to results in India which reported $41 \%$ but less than the results reported in Malaysia. ${ }^{10,11}$ Forty five percent of mothers are changing their children tooth brush after 3 months, while $37 \%$ are changing only when bristles are frayed out, these findings are contrary to reported literature..$^{8,10}$

When parents were asked about the time of consumption of sweet food, $60.7 \%$ replied that upon the demand of child, these findings are greater than those reported from India $(41 \%){ }^{10}$

The limitations of our study are that the results cannot be extrapolated as sample size was small and included limited mothers who were visiting dental centers only. This study needs to be conducted on larger scale with large sample size on different pediatric hospitals to overcome the over estimation of Attitude towards dental treatment. Our population needs awareness programmes regarding oral hygiene practices to bring positive behavioural changes in Parents.

\section{CONCLUSION}

This study found positive association between the age and educational level of parents with their knowledge and practice towards oral hygiene.

\section{CONFLICT OF INTEREST}

None declared.

\section{REFERENCES}

1. Shetty RM, Deoghare A, Rath S, Sarda R, Tamrakar A. Influence of mother's oral health care knowledge on oral health status of their preschool child.Saudi J Oral Sci 2016;3:12-6. https://doi.org/10.4103/1658-6816.174291

2. Virgo-Milton M, Boak R, Hoare A, Gold L, Waters E, Gussy M, Calache H, O'callaghan E, Silva AM. An exploration of the views of Australian mothers on promoting child oral health. Aust Dent J. 2016; 61(1):84-92.

https://doi.org/10.1111/adj.12332

3. Makhdoom S, Khan MA. Assessment of early childhood caries (ecc) and its relationship with feeding practices-a study. Pak Oral Dent J. 2015;35(2)254-57.

4. Zhang X, Yang S, Liao Z, Xu L, Li C, Zeng H, Song J, Zhang L. Prevalence and care in-dex of early childhood caries in mainland China: evidence from epidemiological surveys during 1987-2013. Sci Rep. 2016;6:18897.

5. Wigen TI, Wang NJ. Does early establishment of favorable oral health behavior influence caries experience at age 5 years?. Acta Odontol Scand. 2015;73(3):182-7.

https://doi.org/10.3109/00016357.2014.976264

6. Watanabe M, Wang DH, Ijichi A, Shirai C, Zou Y, Kubo M, Takemoto $\mathrm{K}$, Masatomi C, Ogino K. The influence of lifestyle on the incidence of dental caries among 3-year-old Japa-nese children. Int J Environ Res Public Health. 2014;11(12):12611-22.

https://doi.org/10.3390/ijerph111212611

7. Thomas A, Jacob A, Kunhambu D, Shetty P, Shetty S. Evaluation of the knowledge and attitude of expectant mothers about infant oral health and their oral hygiene practices. J Int Soc Prev Community Dent. 2015;5(5):400-05.

https://doi.org/10.4103/2231-0762.163405

8. Mubeen N, Nisar N. Mother's Knowledge, Attitude and Practices Regarding Dental Caries And Oral Hygiene Among Children (Age 1 To 5 Years) in Civil Hospital, Karachi. Int J Dent Oral Health. 2015;2(4).

9. Arrow P, Raheb J, Miller M. Brief oral health promotion intervention among parents of young children to reduce early childhood dental decay. BMC Public Health. 2013;13(1):245.

https://doi.org/10.1186/1471-2458-13-245

10. JJain R, Oswal KC, Chitguppi R. Knowledge, attitude and practices of mothers toward their children's oral health: A questionnaire survey among subpopulation in Mumbai (India). J Dent Res Sci Develop. 2014;1(2):40-5.

https://doi.org/10.4103/2348-3407.135073

11. Mani SA, John J, Ping WY, Ismail NM. Early childhood caries: parent's knowledge, attitude and practice towards its prevention in Malaysia. Oral Health Care-Pediatr, Res, Epi-demiol \& Clin Pract 2012. InTech. 
12. Mounissamy A, Moses J, Ganesh J, Arulpari M. Evaluation of parental attitude and practice on the primary teeth of their children in Chennai: An hospital survey. Int J Pedod Rehabil. 2016;1(1):10-14.

13. Wyne A. Oral hygiene practices and first dental visit among early childhood caries chil-dren in Riyadh. Pak Oral Dent J. 2003;23 (2):16166.
14. Jaradat T, Moa'th Gh, Showeiter M, Otom A, Kana'an N. The Awareness of Parents of the Time of Eruption of First Permanent Molar and Caries Prevalence in this Tooth In Children in the South of Jordan. Pak Oral Dent J. 2013;33(3):498-501. 